\title{
nnem \\ Review of History of Basic Principles of Burn Wound Management
}

\author{
Hyunjin Kim ${ }^{1}$, Seongmee Shin ${ }^{2}$ and Donghoon Han ${ }^{2, *}$ (1) \\ 1 Department of Plastic Surgery, Hangang Sacred Heart Hospital, Hallym University College of Medicine, \\ Seoul 07247, Korea; msgod456@naver.com \\ 2 Department of Internal Medicine, Kangnam Sacred Heart Hospital, Hallym University College of Medicine, \\ Seoul 07441, Korea; 93tjdal@naver.com \\ * Correspondence: magnox@hallym.or.kr or dhhan.cardio@gmail.com; Tel.: +82-10-9956-5535; \\ Fax: +82-2-2639-5359
}

\begin{abstract}
Thermal energy is an essential and useful resource to humans in modern society. However, a consequence of using heat carelessly is burns. Burn injuries have various causes, such as exposure to flame, radiation, electrical, and chemical sources. In this study, we reviewed the history of burn wound care while focusing on the basic principles of burn management. Through this review, we highlight the need for careful monitoring and customization when treating burn victims at each step of wound care, as their individual needs may differ. We also propose that future research should focus on nanotechnology-based skin grafts, as this is a promising area for further improvement in wound care.
\end{abstract}

Keywords: burn management; antibiotics; fluid resuscitation; history; burn wound care

Citation: Kim, H.; Shin, S.; Han, D. Review of History of Basic Principles of Burn Wound Management.

Medicina 2022, 58, 400. https://

doi.org/10.3390/medicina58030400

Academic Editors: Lars P. Kamolz and Bernd Hartmann

Received: 6 January 2022

Accepted: 28 February 2022

Published: 7 March 2022

Publisher's Note: MDPI stays neutral with regard to jurisdictional claims in published maps and institutional affiliations.

Copyright: (c) 2022 by the authors. Licensee MDPI, Basel, Switzerland. This article is an open access article distributed under the terms and conditions of the Creative Commons Attribution (CC BY) license (https:// creativecommons.org/licenses/by/ $4.0 /)$.

\section{Introduction}

Thermal energy is essential for human life in modern society. However, a consequence of using thermal energy is burns [1]. The skin is made of proteins and acts as a barrier, which protects the organism from the outside environment, regulates body temperature, and prevents fluid loss [1,2]. In a burn injury, this protective barrier is damaged and proper treatment should be provided immediately. Although there are various types of burn injuries, including those due to flame, radiation, electrical, and chemical agents, the goal of all burn management is the same: stop the burning process, minimize scarring, relieve pain, reduce secondary infection, and prevent future complications, such as dysfunction of the injured site or burn shock [3,4]. Early emergency treatment, including aggressive surgical excision, skin regeneration, and pain control, as well as psychological support, should be considered to improve burn management [5-8]. In this paper, we review the history of burn wound care, focusing on the basic principles of burn management.

\section{Medical Approaches}

\subsection{Fluid Resuscitation}

Rapid and adequate intravascular volume supplementation is a cornerstone of the prevention of burn shock [9]. Delayed or inadequate fluid replacement can result in hypovolemia, leading to tissue hypoperfusion, hypovolemic shock, and multiple organ failure [10]. In the 1940s, there were large urban fires, such as the one at the Coconut Grove nightclub (Boston, MA, USA), and physicians found that some patients survived large burns but died from secondary shock [11,12]. Thus began fluid resuscitation studies in severely burned patients. In 1942, Cope and Moore introduced the concept of fluid resuscitation in burn victims, being tailored to individual patient needs [13]. Evans developed a burn surface area-weight formula for the demand of fluid replacement in patients with burns in 1952 [14]. Wallace published the rule of nines, a tool used to assess the total body surface 
area (TBSA) in patients with high-degree burns as a quick and easy assessment tool to ascertain the severity of the burns and intravenous fluid needs (Figure 1) [15,16].
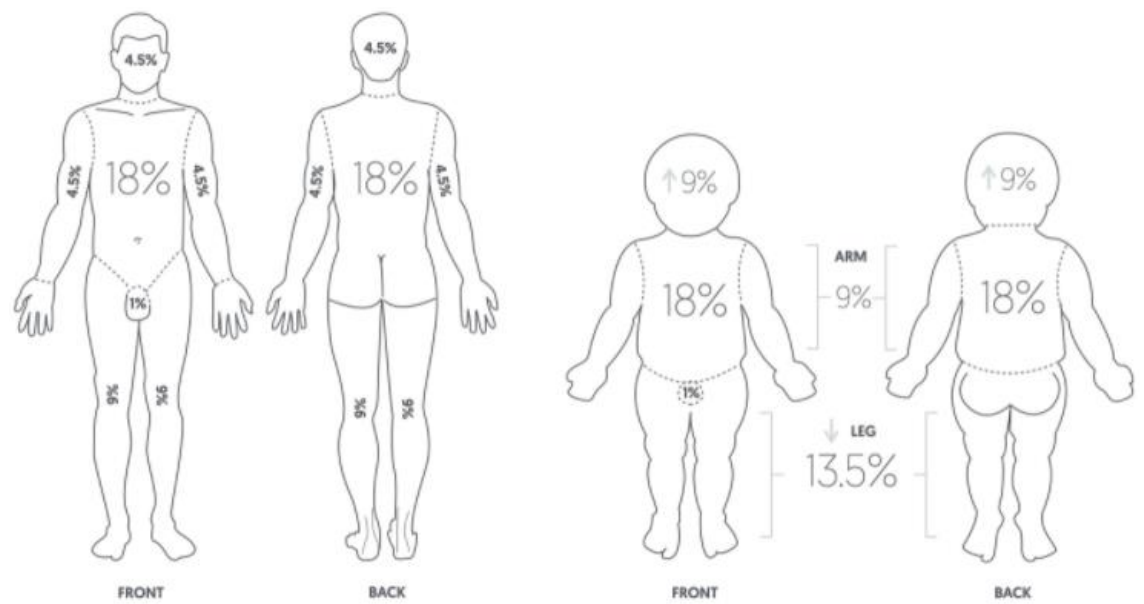

Figure 1. Wallace "rule of nines" for adults and children [17]. With permission from Pulsenotes.

The rule of nines can be modified based on body mass index and age [18,19]. In 1968, Baxter and Shires formulated a measure of fluid volume requirement by weight and percentage of the TBSA, known as the Parkland formula [20,21]. During the 1960s, researchers at the Brooke and Parkland hospitals in Texas developed formulas that only used lactated Ringer's (LR) solution, and no plasma, for the first $24 \mathrm{~h}$ following burn injury [21]. The modified Brooke formula (which estimates the first $24 \mathrm{~h}$ volume as LR solution, $2 \mathrm{~mL} / \mathrm{kg} /$ total body surface area burned (TBSA), with half of this delivered over the first $8 \mathrm{~h}$ ) and the Parkland formula (similar to the Brooke formula but $4 \mathrm{~mL} / \mathrm{kg} / \mathrm{TBSA}$ ) are the most commonly used formulas for resuscitation of adult burn patients today [22]. Albumin replaced plasma in most resuscitation regimens and was primarily used during the second $24 \mathrm{~h}$, at a dose of 0.3 to $0.5 \mathrm{~mL} / \mathrm{kg} / \mathrm{TBSA}$ for the day [22]. However, recent data suggest that the formula does not accurately predict fluid requirements in patients with large burns and that patients recently treated using the formula frequently required higher volumes of fluid than was predicted $[23,24]$. Blumetti et al. reported that only $14 \%$ of adequately resuscitated and $12 \%$ of over-resuscitated patients met the Parkland formula criteria in a retrospective study of patients resuscitated using the formula over a 15-year period [25]. Daniel et al. reported that a restrictive fluid regimen showed a higher survival rate than the liberal Parkland regimen based on data from the German burn registry [26]. Fluid resuscitation formulae are only guides to assist in the estimation of fluid requirements. Therefore, the volume of fluid should be customized for each patient according to the extent of burn injury and patient condition [27]. Regardless of the formula or strategy used, frequent adjustments based on clinical indicators of the adequacy of resuscitation are required in the first $24-48 \mathrm{~h}$ (Table 1) [27]. 
Table 1. Summary of Adult Formulas for burn fluid replacement [28].

\begin{tabular}{|c|c|c|c|c|}
\hline Formula & Crystalloid & Colloid & Glucose & $\begin{array}{l}\text { Instructions for } \\
\text { Administration }\end{array}$ \\
\hline Cope and Moore & $\begin{array}{c}75 \mathrm{~mL} / \% \text { TBSA burn oral } \\
\text { electrolyte replacement } \\
\text { solution }\end{array}$ & 75 mL/\%TBSA burn FFP & $\begin{array}{l}2000 \mathrm{~mL} \text { fruit juice PO or } \\
2000 \mathrm{~mL} \mathrm{5 \%} \text { dextrose IV }\end{array}$ & $\begin{array}{l}\text { Half over the first } 8 \mathrm{~h} \text {, half } \\
\text { over the second } 16 \mathrm{~h}\end{array}$ \\
\hline Evans & $1 \mathrm{~mL} / \mathrm{kg} / \%$ TBSA burn of NS & $1 \mathrm{~mL} / \mathrm{kg} / \%$ TBSA burn FFP & $2000 \mathrm{~mL} \mathrm{5 \%} \mathrm{dextrose}$ & $\begin{array}{l}\text { Half over the first } 8 \mathrm{~h} \text {, half } \\
\text { over the second } 16 \mathrm{~h}\end{array}$ \\
\hline Brooke & $1.5 \mathrm{~mL} / \mathrm{kg} / \%$ TBSA burn of LR & $\begin{array}{c}0.5 \mathrm{~mL} / \mathrm{kg} / \% \text { TBSA burn } \\
\text { FFP }\end{array}$ & $2000 \mathrm{~mL} \mathrm{5 \%} \mathrm{dextrose}$ & $\begin{array}{c}\text { Half over first } 8 \mathrm{~h} \text {, half } \\
\text { over second } 16 \mathrm{~h}\end{array}$ \\
\hline Parkland & $4 \mathrm{~mL} / \mathrm{kg} / \%$ TBSA burn of LR & None & None & $\begin{array}{l}\text { Half over the first } 8 \mathrm{~h} \text {, half } \\
\text { over the second } 16 \mathrm{~h}\end{array}$ \\
\hline Modifed Brooke & $2 \mathrm{~mL} / \mathrm{kg} / \%$ TBSA burn of LR & None & None & $\begin{array}{l}\text { Half over the first } 8 \mathrm{~h} \text {, half } \\
\text { over the second } 16 \mathrm{~h}\end{array}$ \\
\hline
\end{tabular}

Abbreviations: \%TBSA, percent total body surface area; NS, normal saline; LR, lactated Ringer's; FFP, fresh frozen plasma.

\subsection{Nutrition for Wound Healing}

Providing adequate nutrition is important for burn wound healing and recovery $[29,30]$. Aggressive feeding in children is associated with decreased muscle protein catabolism, a reduced rate of burn sepsis, and lower bacterial counts from excised tissue [31]. Similarly, in adults, early nutritional support is associated with shorter hospital stays, faster wound healing, and reduced risk of infection [32]. However, several nutritional factors must be carefully considered. Excess carbohydrate consumption can lead to hyperglycemia, which can aggravate systemic inflammation and muscle degradation [33-35]. Excess fat supply may exaggerate the immunosuppressed state, and since major burn injuries may also result in immunosuppression, this result may increase the risk of infection and sepsis $[30,36,37]$. Proteins play an essential role in every step of the wound-healing process. Proteins are necessary for collagen synthesis, angiogenesis, fibroblast proliferation, immune function, tissue remodeling, wound contraction, and skin structural proteins [30,38]. Moreover, leukocytes, monocytes, lymphocytes, and macrophages require protein for their formation and function in mounting an immune response. Protein deficiency results in impaired fibroblast proliferation and collagen synthesis during the proliferative phase of healing $[39,40]$.

\subsection{Control of Infection in Burns}

Wound infection, including sepsis, is the most serious complication of burns in the acute period following burn injury [41,42]. Approximately $73-85 \%$ of all deaths that occur within the first 5 days of injury are due to sepsis [43-45]. Colebrook first introduced the concept of safeguarding burn wounds from infection. He suggested that burn wounds could easily be infected with bacteria; thus, strict infection control could help prevent wound infection by reducing the transfer of organisms among patients in a burn center [46,47].

When administering systemic antibacterial agents to burn patients, clinicians should carefully consider the emergence of antibiotic-resistant organisms [48]. Coban provided two suggestions to overcome infection by resistant microorganisms: (1) the burn center should maintain quality control against microorganisms, and antibiotic agent administration should consider the antibiotic resistance trends within each burn center; (2) systemic antibiotics should only be administered for a short period to patients with burns [49]. Prophylactic use of antibiotics enables the development of secondary infections (commonly diarrhea); therefore, it should not be applied routinely in all burn cases [49]. Prophylactic use is recommended only during the immediate perioperative period surrounding excision or grafting of the burn wound when there is an increased risk of bacteremia. Antibiotic therapy should be started immediately before the procedure and should generally be discontinued within $24 \mathrm{~h} \mathrm{[48].} \mathrm{Most} \mathrm{importantly,} \mathrm{clinicians} \mathrm{must} \mathrm{try} \mathrm{to} \mathrm{prevent} \mathrm{burn}$ wound infection by monitoring alterations in the wound character, odor, or amount of pus drainage at the time of each dressing change, and by practicing aseptic dressing techniques, 
particularly when handling the open wound and dressing materials. In addition, the frequency of dressing should be based on the wound condition [48].

\section{Surgical Approaches}

\subsection{Burn Wound Dressing}

Wound dressings and healing agents are routinely used to treat burn wounds [50]. Burn dressings can protect the skin from infection and further skin damage, promote re-epithelialization, and decrease pain [11,51]. Humidity and heat-preserving dressings, as well as moist dressings, are recommended for burns [52]. An ideal dressing that provides a moist and humid environment for wound healing has not been identified thus far [52-54]. Small burns can be effectively treated with simple dressings, but more careful management is necessary for larger burns to reduce body fluid loss caused by damage to the skin barrier [55].

In 1500, Pare treated burn wounds with onion. This is the first description of burn wound management using dressings [51]. In 1797, Kentish reported that pressure dressings could alleviate burn pain and blisters. In 1839, Dupuytren reviewed treatment with occlusive dressings and developed a classification of burn depth that is still widely used [56-58].

More recently used dressings for burn wounds can be divided into four categories: (i) Biological dressings, including allograft, xenograft, and human amnion. These dressings effectively promote the healing of wounds for further skin grafting; however, they cannot replace permanent skin and are associated with inconsistent quality, limited supply, and increased risk of bacterial pathogen transfer $[11,59,60]$. (ii) Conventional dressings use Vaseline gauze or silicone sheets. Although these dressings are widely used, they tend to stick to the wound surface, which can damage the newly epithelialized surface and delay wound healing $[51,61]$. Nevertheless, Lucattelli et al. reported that applying silicone gel was particularly effective in re-epithelialization despite physically and biologically interacting with injured tissue [62]. In addition, Xeroform gauze is useful for superficial, partial-thickness burns and split-thickness skin graft donor sites [63-65]. Xeroform consists of a mixture of petroleum jelly and bismuth tribromophenate. Petroleum jelly of Xeroform creates an occlusive, nonadhesive barrier that helps the wound to remain moist, and bismuth tribromophenate has an antimicrobial effect [64,66]. (iii) Biosynthetic dressings use a material functionally similar to skin [11]. Biobrane ${ }^{\mathrm{TM}}$ is a biosynthetic dressing recommended for superficial, partial-thickness burns [67]. It is made from a porcine dermal collagen-bonded nylon membrane on silicon scaffolding. The collagen component initially adheres to the fibrin on a clean wound surface, and this adherence contributes to pain reduction. The silicone outer layer can prevent excessive water loss, thereby promoting a desirable moist environment for wound healing. Its transparency also allows for inspection to assess the wound condition [68]. However, nowadays, this material is not routinely used. The most widely used dermal regeneration template is Integra (Integra LifeScience Corporation, Plainsboro, NJ, USA), which is a bilayer composed of a matrix of bovine collagen cross-linked with glycosaminoglycans from shark chondroitin sulfate with an overlying protective silicone layer [69]. The use of Integra templates in reconstructive surgery has been described in burns, scalp, limbs, abdominal wall, degloving injuries, keloids, hypertrophic scars, diabetic foot ulcers, and necrotizing soft-tissue infections among other uses (Figure 2) [70-77]. Although Integra has been shown to be an effective reconstructive tool with excellent functional outcomes, aesthetic results, and high rates of long-term engraftment, infection associated with Integra use was the most common complication [78-82]. (iv) Antimicrobial dressings are widely used in burn management to prevent wound infection. Antimicrobial dressings use products containing silver, nanocrystalline silver, iodine (cadexomer or povidone iodine), or honey and mafenide acetate, all of which can prevent bacterial colonization [11,83-87]. The usefulness and effect of silver for wound treatment has been known since $69 \mathrm{BC}$ [88]. Silver sulfadiazine is widely used for the management of second-degree burns, but it has poor outcomes in burn wound care, particularly with respect to infection and epithelialization [89-91]. Nanocrystalline 
silver dressings were developed and introduced in the late 1990s and are the latest forms of silver-based wound dressings. These products were developed to overcome some of the weaknesses of earlier silver dressings [92]. Dressings with nanocrystalline silver are superior to silver sulfadiazine and silver-free dressings for burns in terms of epithelialization, infection, and pain control [93-96].

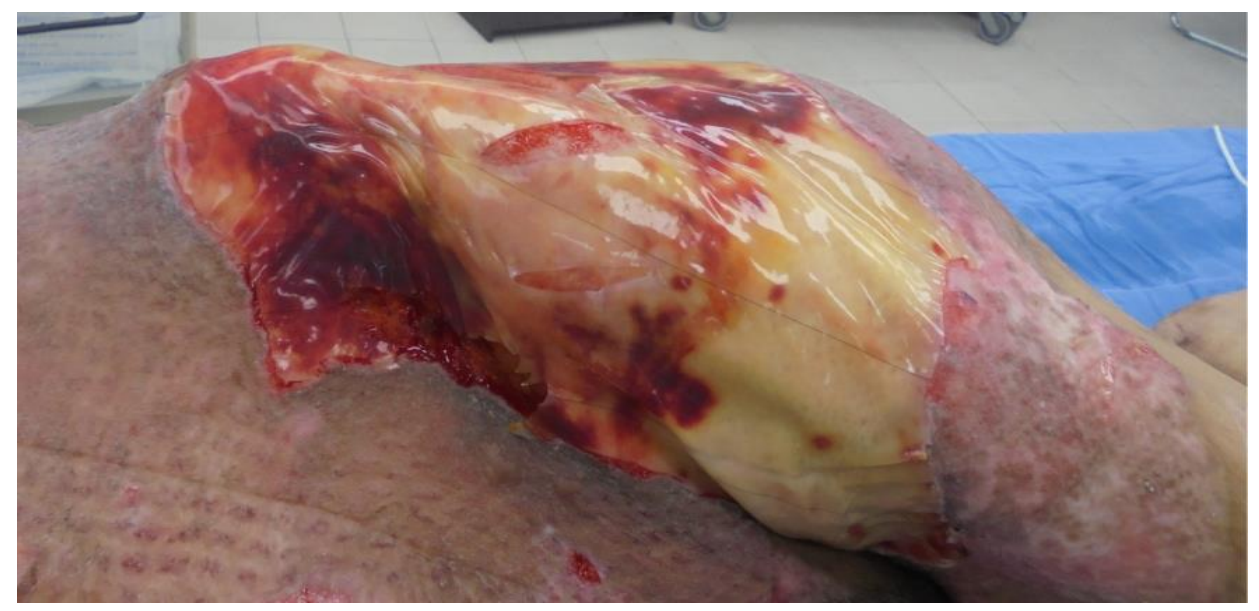

Figure 2. Integra applied on burn wound.

Iodine is a well-known antiseptic agent that is widely used in wound dressing [97]. Povidone iodine does not cause a delay in wound healing or have harmful effects in patients with burns [98-100]. Cadexomer iodine is a slow-release antimicrobial agent that can absorb excess wound exudates while maintaining a sustained level of iodine in the wound. Although studies on the effect of cadexomer iodine in patients with burns is lacking, it is effective against antibiotic-resistant bacteria [101].

Honey has antibacterial properties and enhances tissue growth [102,103]. Several studies have revealed that dressing with honey had a better outcome than dressing with silver [104-107].

Mafenide acetate (Sulfamylon) is a widely used antimicrobial agent to prevent bacterial infection on a variety of burn wounds, such as full-thickness burns and burns with eschar, post-excision, and autograft [87,108-111]. Sulfamylon inhibits the nucleotide synthesis of bacteria, and it has bacteriostatic effects on Gram-positive and Gram-negative organisms [112,113]. Sulfamylon was used in a 10\% topical water-soluble cream in 1964 [114]. However, the high osmolality of $10 \%$ Sulfamylon cream was associated with neoeschar formation and wound pain [112,115]. Several animal experiments and clinical studies demonstrated that the use of 5\% Sulfamylon solution dressing provided a better result with less side effects [116-118]. Finally, the 5\% Sulfamylon became widely used for burn wound treatment [108].

\subsection{Surgical Treatment of Burns}

Surgical treatment of burns includes two procedures, namely, skin excision and skin grafting. In 1607, Hildanus mentioned that the removal of burn eschars could facilitate drainage of serous fluid and allow for better medication penetration [119]. Young, McCorkle, and Silvani, and Saltonstall and Lee reported successful experiences with surgical excision and skin grafting in patients with deep burn wounds [120-122]. In the 1970s, Janzekovie introduced tangential excision, in which early excision of burns resulted in better prognosis [123]. Subsequently, Monafo performed tangential excision and grafting for the treatment of patients with larger burns [124]. In a randomized, prospective study, Engrav et al. reported that early tangential excision and grafting of deep second-degree burns improved outcomes, such as reduced mortality and hospitalization duration, compared to conservative treatment methods [125]. Tompkins et al. reported that prompt eschar excision reduced mortality in a retrospective study from 1974 to 1984 [126]. Saaiq 
et al. also reported that early excision and grafting had better outcomes in terms of graft take, post-graft hospitalization, and mortality, in patients with deep burns covering up to $40 \%$ of the TBSA [127].

Early excision is defined as excision of the entire burn wound within $24 \mathrm{~h}$ to approximately 7 days [128-131]. A recent meta-analysis found that early excision of burns was beneficial in reducing mortality in patients without inhalational injury [130]. However, the optimal timing for early excision still remains controversial. Moussa et al. reported that early excision, within $24 \mathrm{~h}$, resulted in better outcomes, but that delayed excision, up to $72 \mathrm{~h}$ after the burn injury, might be reasonable in selected patients [132].

Negative pressure wound therapy (NPWT), including topical negative pressure therapy and vacuum-assisted closure, has been used in the context of open-wound management; the interface foam is applied directly to the wound bed, which is visible at the body surface $[133,134]$. NPWT has been applied to various surgical wounds since 1997 [135]. It can accelerate wound healing on both acute and chronic wounds, and it has been widely used on wounds with soft tissue defects $[136,137]$. Although the mechanism of NPWT promoting wound healing is not fully understood, some researchers suggest that it may contribute to maintaining a moist environment for wounds, removing inflammatory exudate from the wound, and reducing exposure to pathogens [138,139]. NPWT improved the outcomes of various aspects of burn wound care, including acute burns, autografts, skin grafts, donor sites, and large burns [140-144]. Although further research is needed to explore the clinical application of NPWT for burns, it has proven to be a beneficial aspect in various aspects of burn wound care.

Skin grafts may be surgically attached to the burn site to promote healing. Two types of grafts, autografts and allografts, can be used to cover the wound bed [145]. Girdner reported the first successful use of allografts in severe and extensive burn wounds in 1881 [146]. In 1954, Jackson introduced a combined grafting technique using narrow strips of allograft and autograft in a granulating or excised wound [147]. Alexander et al. developed a simple technique, which applied a widely meshed skin autograft and then covered it with allogenic skin [148].

Despite their imperfections, existing dressings and tissue-engineered skin substitutes have significantly improved clinical outcomes for burn victims, leading to increased survival rates and improved quality of life $[61,149,150]$. Stem cells derived from various sources have been used for their regenerative properties [151,152]. However, further research is needed for the use of stem cells in burn management. Nowadays, cells, biomaterial, and delivery-based materials are routinely used when designing skin substitutes [151,153,154]. Furthermore, emerging nano-based therapeutic systems, such as nanoparticles (nonpolymeric and polymeric) and scaffolds (nanofibers, films and membranes, foams and sponges, and hydrogels), are also being used in burn-wound-healing processes. Nanomedicine shows great potential to improve and enhance the healing process in burn wounds. However, future research on nanomedicine, along with toxicology and safety assessments, will be necessary for further development [155].

\section{Conclusions}

In modern society, thermal energy is an essential resource; however, its use increases the risk of sustaining burns. Evidence-based treatment plans can improve the survival of patients with burns and lead to better prognosis. Many advanced techniques have been developed for burn wound care, and several materials have been developed to reconstruct burnt skin and treat deformities. In the future, active research on skin recovery should be conducted to improve the management of burn wounds.

Author Contributions: Conceptualization, D.H.; resources, H.K., S.S. and D.H.; writing-original draft preparation, H.K. and D.H.; writing_-review and editing, D.H.; visualization, H.K. and D.H.; supervision, D.H. All authors have read and agreed to the published version of the manuscript.

Funding: This research received no external funding. 


\section{Institutional Review Board Statement: Not applicable.}

Informed Consent Statement: We explained and received the patient's agreement for Figure 2.

Data Availability Statement: All information included in this review is documented by relevant references.

Conflicts of Interest: The authors declare no conflict of interest.

\section{References}

1. Society, K.B. Total Burn Care; Koonja Publishing: Seoul, Korea, 2021; pp. 1-18.

2. Proksch, E.; Brandner, J.M.; Jensen, J.M. The skin: An indispensable barrier. Exp. Dermatol. 2008, 17, 1063-1072. [CrossRef] [PubMed]

3. Vivo, C.; Galeiras, R.; del Caz, M.D. Initial evaluation and management of the critical burn patient. Med. Intensiva 2016, 40, 49-59. [CrossRef] [PubMed]

4. Ansermino, M.; Hemsley, C. Intensive care management and control of infection. BMJ 2004, 329, 220-223. [CrossRef] [PubMed]

5. Patterson, D.R.; Jensen, M.P. Hypnosis and clinical pain. Psychol. Bull. 2003, 129, 495-521. [CrossRef]

6. Romanowski, K.S.; Carson, J.; Pape, K.; Bernal, E.; Sharar, S.; Wiechman, S.; Carter, D.; Liu, Y.M.; Nitzschke, S.; Bhalla, P.; et al. American Burn Association Guidelines on the Management of Acute Pain in the Adult Burn Patient: A Review of the Literature, a Compilation of Expert Opinion, and Next Steps. J. Burn. Care Res. 2020, 41, 1129-1151. [CrossRef]

7. Shpichka, A.; Butnaru, D.; Bezrukov, E.A.; Sukhanov, R.B.; Atala, A.; Burdukovskii, V.; Zhang, Y.; Timashev, P. Skin tissue regeneration for burn injury. Stem. Cell Res. Ther. 2019, 10, 94. [CrossRef] [PubMed]

8. Browne, A.L.; Andrews, R.; Schug, S.A.; Wood, F. Persistent pain outcomes and patient satisfaction with pain management after burn injury. Clin. J. Pain 2011, 27, 136-145. [CrossRef]

9. Bittner, E.A.; Shank, E.; Woodson, L.; Martyn, J.A. Acute and perioperative care of the burn-injured patient. Anesthesiology 2015, 122, 448-464. [CrossRef]

10. Barrow, R.E.; Jeschke, M.G.; Herndon, D.N. Early fluid resuscitation improves outcomes in severely burned children. Resuscitation 2000, 45, 91-96. [CrossRef]

11. Wang, Y.; Beekman, J.; Hew, J.; Jackson, S.; Issler-Fisher, A.C.; Parungao, R.; Lajevardi, S.S.; Li, Z.; Maitz, P.K.M. Burn injury: Challenges and advances in burn wound healing, infection, pain and scarring. Adv. Drug. Deliv. Rev. 2018, 123, 3-17. [CrossRef]

12. Endorf, F.W.; Dries, D.J. Burn resuscitation. Scand. J. Trauma Resusc. Emerg. Med. 2011, 19, 69. [CrossRef] [PubMed]

13. Cope, O.; Moore, F.D. The Redistribution of Body Water and the Fluid Therapy of the Burned Patient. Ann. Surg. 1947, 126, 1010-1045. [CrossRef] [PubMed]

14. Evans, E.I.; Purnell, O.J.; Robinett, P.W.; Batchelor, A.; Martin, M. Fluid and electrolyte requirements in severe burns. Ann. Surg. 1952, 135, 804-817. [CrossRef] [PubMed]

15. Wallace, A.B. The exposure treatment of burns. Lancet 1951, 1, 501-504. [CrossRef]

16. Livingston, E.H.; Lee, S. Percentage of burned body surface area determination in obese and nonobese patients. J. Surg. Res. 2000, 91, 106-110. [CrossRef]

17. Bourdon, R.T.; Nelson-Cheeseman, B.B.; Abraham, J.P. Review of the initial treatment and avoidance of scald injuries. World J. Dermatol. 2017, 6, 17-26. [CrossRef]

18. Borhani-Khomani, K.; Partoft, S.; Holmgaard, R. Assessment of burn size in obese adults; a literature review. J. Plast. Surg. Hand Surg. 2017, 51, 375-380. [CrossRef]

19. Moore, R.A.; Waheed, A.; Burns, B. Rule of Nines; StatPearls Publishing: Treasure Island, FL, USA, 2021.

20. Alvarado, R.; Chung, K.K.; Cancio, L.C.; Wolf, S.E. Burn resuscitation. Burns 2009, 35, 4-14. [CrossRef]

21. Baxter, C.R.; Shires, T. Physiological response to crystalloid resuscitation of severe burns. Ann. N. Y. Acad. Sci. 1968, 150, 874-894. [CrossRef]

22. Greenhalgh, D.G. Burn resuscitation: The results of the ISBI/ABA survey. Burns 2010, 36, 176-182. [CrossRef]

23. Pruitt, B.A., Jr. Protection from excessive resuscitation: "pushing the pendulum back". J. Trauma 2000, 49, 567-568. [CrossRef] [PubMed]

24. Friedrich, J.B.; Sullivan, S.R.; Engrav, L.H.; Round, K.A.; Blayney, C.B.; Carrougher, G.J.; Heimbach, D.M.; Honari, S.; Klein, M.B.; Gibran, N.S. Is supra-Baxter resuscitation in burn patients a new phenomenon? Burns 2004, 30, 464-466. [CrossRef] [PubMed]

25. Blumetti, J.; Hunt, J.L.; Arnoldo, B.D.; Parks, J.K.; Purdue, G.F. The Parkland formula under fire: Is the criticism justified? J. Burn Care Res. 2008, 29, 180-186. [CrossRef] [PubMed]

26. Daniels, M.; Fuchs, P.C.; Lefering, R.; Grigutsch, D.; Seyhan, H.; Limper, U.; The German Burn, R.; Schiefer, J.L. Is the Parkland formula still the best method for determining the fluid resuscitation volume in adults for the first $24 \mathrm{~h}$ after injury?-A retrospective analysis of burn patients in Germany. Burns 2021, 47, 914-921. [CrossRef] [PubMed]

27. Hettiaratchy, S.; Papini, R. Initial management of a major burn: II-assessment and resuscitation. BMJ 2004, 329, 101-103. [CrossRef]

28. Romanowski, K.S.; Palmieri, T.L. Pediatric burn resuscitation: Past, present, and future. Burn. Trauma 2017, 5, 26. [CrossRef] 
29. Andel, H.; Kamolz, L.P.; Horauf, K.; Zimpfer, M. Nutrition and anabolic agents in burned patients. Burns 2003, $29,592-595$. [CrossRef]

30. Abdullahi, A.; Jeschke, M.G. Nutrition and anabolic pharmacotherapies in the care of burn patients. Nutr. Clin. Pract. 2014, 29, 621-630. [CrossRef]

31. Hart, D.W.; Wolf, S.E.; Chinkes, D.L.; Beauford, R.B.; Mlcak, R.P.; Heggers, J.P.; Wolfe, R.R.; Herndon, D.N. Effects of early excision and aggressive enteral feeding on hypermetabolism, catabolism, and sepsis after severe burn. J. Trauma 2003, 54, 755-761. [CrossRef]

32. Mosier, M.J.; Pham, T.N.; Klein, M.B.; Gibran, N.S.; Arnoldo, B.D.; Gamelli, R.L.; Tompkins, R.G.; Herndon, D.N. Early enteral nutrition in burns: Compliance with guidelines and associated outcomes in a multicenter study. J. Burn Care Res. 2011, 32, 104-109. [CrossRef]

33. Mecott, G.A.; Al-Mousawi, A.M.; Gauglitz, G.G.; Herndon, D.N.; Jeschke, M.G. The role of hyperglycemia in burned patients: Evidence-based studies. Shock 2010, 33, 5-13. [CrossRef] [PubMed]

34. Gore, D.C.; Chinkes, D.L.; Hart, D.W.; Wolf, S.E.; Herndon, D.N.; Sanford, A.P. Hyperglycemia exacerbates muscle protein catabolism in burn-injured patients. Crit. Care Med. 2002, 30, 2438-2442. [CrossRef] [PubMed]

35. Kulp, G.A.; Tilton, R.G.; Herndon, D.N.; Jeschke, M.G. Hyperglycemia exacerbates burn-induced liver inflammation via noncanonical nuclear factor-kappaB pathway activation. Mol. Med. 2012, 18, 948-956. [CrossRef] [PubMed]

36. Cunningham-Rundles, S.; McNeeley, D.F.; Moon, A. Mechanisms of nutrient modulation of the immune response. J. Allergy Clin. Immunol. 2005, 115, 1119-1128; quiz 1129. [CrossRef]

37. Schwacha, M.G.; Chaudry, I.H. The cellular basis of post-burn immunosuppression: Macrophages and mediators. Int. J. Mol. Med. 2002, 10, 239-243. [CrossRef]

38. Harris, C.L.; Fraser, C. Malnutrition in the institutionalized elderly: The effects on wound healing. Ostomy Wound Manag. 2004, $50,54-63$.

39. White, J.V.; Guenter, P.; Jensen, G.; Malone, A.; Schofield, M.; Academy Malnutrition Work, G.; Academy Malnutrition Work Group; A.S.P.E.N. Malnutrition Task Force; A.S.P.E.N. Board of Directors. Consensus statement: Academy of Nutrition and Dietetics and American Society for Parenteral and Enteral Nutrition: Characteristics recommended for the identification and documentation of adult malnutrition (undernutrition). JPEN J. Parenter. Enteral Nutr. 2012, 36, 275-283. [CrossRef]

40. Doughty, D.B.; Sparks-Defriese, B. Wound healing physiology. In Acute and Chronic Wounds: Current Management Concepts, 4th ed.; Mosby-Elsevier: St Louis, MO, USA, 2012; pp. 63-82.

41. Appelgren, P.; Bjornhagen, V.; Bragderyd, K.; Jonsson, C.E.; Ransjo, U. A prospective study of infections in burn patients. Burns 2002, 28, 39-46. [CrossRef]

42. Dodd, D.; Stutman, H.R. Current issues in burn wound infections. Adv. Pediatr. Infect. Dis. 1991, 6, 137-162.

43. Tancheva, D.; Hadjiiski, O. Effect of early nutritional support on clinical course and septic complications in patients with severe burns. Ann. Burn. Fire Disasters 2005, 18, 74-78.

44. Church, D.; Elsayed, S.; Reid, O.; Winston, B.; Lindsay, R. Burn wound infections. Clin. Microbiol. Rev. 2006, 19, 403-434. [CrossRef] [PubMed]

45. Bang, R.L.; Sharma, P.N.; Sanyal, S.C.; Al Najjadah, I. Septicaemia after burn injury: A comparative study. Burns 2002, 28 , 746-751. [CrossRef]

46. Turk, J.L. Leonard Colebrook: The chemotherapy and control of streptococcal infections. J. R. Soc. Med. 1994, 87, 727-728. [PubMed]

47. Colebrook, L.; Kenny, M. Treatment of human puerperal infections, and of experimental infections in mice, with prontosil. Lancet 1936, 227, 1279-1281. [CrossRef]

48. Weber, J.; McManus, A.; Nursing Committee of the International Society for Burn Injuries. Infection control in burn patients. Burns 2004, 30, A16-A24. [CrossRef]

49. Coban, Y.K. Infection control in severely burned patients. World J. Crit. Care Med. 2012, 1, 94-101. [CrossRef]

50. Roshangar, L.; Soleimani Rad, J.; Kheirjou, R.; Reza Ranjkesh, M.; Ferdowsi Khosroshahi, A. Skin Burns: Review of Molecular Mechanisms and Therapeutic Approaches. Wounds 2019, 31, 308-315.

51. Liu, H.F.; Zhang, F.; Lineaweaver, W.C. History and Advancement of Burn Treatments. Ann. Plast. Surg. 2017, 78, S2-S8. [CrossRef]

52. Committee, I.P.G.; Steering, S.; Advisory, S. ISBI Practice Guidelines for Burn Care. Burns 2016, 42, 953-1021. [CrossRef]

53. Dinah, F.; Adhikari, A. Gauze packing of open surgical wounds: Empirical or evidence-based practice? Ann. R. Coll. Surg. Engl. 2006, 88, 33-36. [CrossRef]

54. Jones, V.; Grey, J.E.; Harding, K.G. Wound dressings. BMJ 2006, 332, 777-780. [CrossRef] [PubMed]

55. Muller, M.; Gahankari, D.; Herndon, D.N. Chap 12 operative wound management. In Total Burn Care, 5th ed.; Elservier: Amsterdam, The Netherlands, 2018.

56. Ribeiro, P.S.; Jacobsen, K.H.; Mathers, C.D.; Garcia-Moreno, C. Priorities for women's health from the Global Burden of Disease study. Int. J. Gynaecol. Obstet. 2008, 102, 82-90. [CrossRef] [PubMed]

57. JL, R. Graffe epidermique. Experience faite dans le service de M. le docteur Guyon, a l'hopital Necker. Bull. Imp. Soc. Chir. Paris 1869, 10, 511-515.

58. Curling, T.B. On acute ulceration of the duodenum, in cases of burn. Med. Chir. Trans. 1842, 25, 260-281. [CrossRef] [PubMed] 
59. Atiyeh, B.S.; Gunn, S.W.; Hayek, S.N. State of the art in burn treatment. World J. Surg. 2005, 29, 131-148. [CrossRef]

60. Garfein, E.S.; Orgill, D.P.; Pribaz, J.J. Clinical applications of tissue engineered constructs. Clin. Plast. Surg. 2003, 30, 485-498. [CrossRef]

61. Boateng, J.; Catanzano, O. Advanced Therapeutic Dressings for Effective Wound Healing-A Review. J. Pharm. Sci. 2015, 104, 3653-3680. [CrossRef]

62. Lucattelli, E.; Cipriani, F.; Pascone, C.; Di Lonardo, A. Non-Healing Burn Wound Treatment with A Sterile Silicone Gel. Ann. Burn. Fire Disasters 2021, 34, 53-57.

63. Malpass, K.G.; Snelling, C.F.; Tron, V. Comparison of donor-site healing under Xeroform and Jelonet dressings: Unexpected findings. Plast. Reconstr. Surg. 2003, 112, 430-439. [CrossRef]

64. Hansbrough, W.; Dore, C.; Hansbrough, J.F. Management of skin-grafted burn wounds with Xeroform and layers of dry coarse-mesh gauze dressing results in excellent graft take and minimal nursing time. J. Burn. Care Rehabil. 1995, 16, 531-534. [CrossRef]

65. Masella, P.C.; Balent, E.M.; Carlson, T.L.; Lee, K.W.; Pierce, L.M. Evaluation of Six Split-thickness Skin Graft Donor-site Dressing Materials in a Swine Model. Plast. Reconstr. Surg. Glob. Open. 2013, 1, e84. [CrossRef] [PubMed]

66. Dodge, A.G.; Wackett, L.P. Metabolism of bismuth subsalicylate and intracellular accumulation of bismuth by Fusarium sp. strain BI. Appl. Env. Microbiol. 2005, 71, 876-882. [CrossRef] [PubMed]

67. Demling, R.H. Use of Biobrane in management of scalds. J. Burn. Care Rehabil. 1995, 16, 329-330. [CrossRef] [PubMed]

68. Whitaker, I.S.; Prowse, S.; Potokar, T.S. A critical evaluation of the use of Biobrane as a biologic skin substitute: A versatile tool for the plastic and reconstructive surgeon. Ann. Plast Surg. 2008, 60, 333-337. [CrossRef]

69. Integra Dermal Regeneration Template-How INTEGRA Works. Available online: http://www.ilstraining.com/idrt/idrt/brs_ it_04.htm (accessed on 10 June 2021).

70. Corradino, B.; Di Lorenzo, S.; Leto Barone, A.A.; Maresi, E.; Moschella, F. Reconstruction of full thickness scalp defects after tumour excision in elderly patients: Our experience with Integra dermal regeneration template. J. Plast. Reconstr. Aesthet. Surg. 2010, 63, e245-e247. [CrossRef]

71. Gonyon, D.L., Jr.; Zenn, M.R. Simple approach to the radiated scalp wound using INTEGRA skin substitute. Ann. Plast. Surg. 2003, 50, 315-320. [CrossRef]

72. Rodriguez Collazo, E.R.; Rathbone, C.R.; Barnes, B.R. A Retrospective Look at Integrating a Novel Regenerative Medicine Approach in Plastic Limb Reconstruction. Plast. Reconstr. Surg. Glob. Open. 2017, 5, e1214. [CrossRef]

73. Jeng, J.C.; Fidler, P.E.; Sokolich, J.C.; Jaskille, A.D.; Khan, S.; White, P.M.; Street, J.H., 3rd; Light, T.D.; Jordan, M.H. Seven years' experience with Integra as a reconstructive tool. J. Burn. Care Res. 2007, 28, 120-126. [CrossRef]

74. Herlin, C.; Louhaem, D.; Bigorre, M.; Dimeglio, A.; Captier, G. Use of Integra in a paediatric upper extremity degloving injury. J. Hand Surg. Eur. Vol. 2007, 32, 179-184. [CrossRef]

75. Clayman, M.A.; Clayman, S.M.; Mozingo, D.W. The use of collagen-glycosaminoglycan copolymer (Integra) for the repair of hypertrophic scars and keloids. J. Burn. Care Res. 2006, 27, 404-409. [CrossRef]

76. Rashid, O.M.; Nagahashi, M.; Takabe, K. Management of massive soft tissue defects: The use of INTEGRA(R) artificial skin after necrotizing soft tissue infection of the chest. J. Thorac. Dis. 2012, 4, 331-335. [CrossRef] [PubMed]

77. Driver, V.R.; Lavery, L.A.; Reyzelman, A.M.; Dutra, T.G.; Dove, C.R.; Kotsis, S.V.; Kim, H.M.; Chung, K.C. A clinical trial of Integra Template for diabetic foot ulcer treatment. Wound Repair Regen. 2015, 23, 891-900. [CrossRef] [PubMed]

78. Heimbach, D.; Luterman, A.; Burke, J.; Cram, A.; Herndon, D.; Hunt, J.; Jordan, M.; McManus, W.; Solem, L.; Warden, G.; et al. Artificial dermis for major burns. A multi-center randomized clinical trial. Ann. Surg. 1988, 208, 313-320. [CrossRef] [PubMed]

79. Heimbach, D.M.; Warden, G.D.; Luterman, A.; Jordan, M.H.; Ozobia, N.; Ryan, C.M.; Voigt, D.W.; Hickerson, W.L.; Saffle, J.R.; DeClement, F.A.; et al. Multicenter postapproval clinical trial of Integra dermal regeneration template for burn treatment. J. Burn Care Rehabil. 2003, 24, 42-48. [CrossRef] [PubMed]

80. Branski, L.K.; Herndon, D.N.; Pereira, C.; Mlcak, R.P.; Celis, M.M.; Lee, J.O.; Sanford, A.P.; Norbury, W.B.; Zhang, X.J.; Jeschke, M.G. Longitudinal assessment of Integra in primary burn management: A randomized pediatric clinical trial. Crit. Care Med. 2007, 35, 2615-2623. [CrossRef] [PubMed]

81. Yannas, I.V.; Orgill, D.P.; Burke, J.F. Template for skin regeneration. Plast. Reconstr. Surg. 2011, 127 (Suppl. 1), 60S-70S. [CrossRef]

82. Muangman, P.; Deubner, H.; Honari, S.; Heimbach, D.M.; Engrav, L.H.; Klein, M.B.; Gibran, N.S. Correlation of clinical outcome of integra application with microbiologic and pathological biopsies. J. Trauma. 2006, 61, 1212-1217. [CrossRef]

83. Demling, R.H.; Leslie DeSanti, M.D. The rate of re-epithelialization across meshed skin grafts is increased with exposure to silver. Burns 2002, 28, 264-266. [CrossRef]

84. Dunn, K.; Edwards-Jones, V. The role of Acticoat with nanocrystalline silver in the management of burns. Burns 2004,30 (Suppl. 1), S1-S9. [CrossRef]

85. Lipsky, B.A.; Hoey, C. Topical antimicrobial therapy for treating chronic wounds. Clin. Infect. Dis. 2009, 49, 1541-1549. [CrossRef]

86. Subrahmanyam, M. Topical application of honey for burn wound treatment-An overview. Ann. Burn. Fire Disasters 2007, 20, 137-139.

87. Shuck, J.M.; Thorne, L.W.; Cooper, C.G. Mafenide acetate solution dressings: An adjunct in burn wound care. J. Trauma 1975, 15, 595-599. [CrossRef] [PubMed] 
88. Murphy, P.S.; Evans, G.R. Advances in wound healing: A review of current wound healing products. Plast. Surg. Int. 2012, 2012, 190436. [CrossRef]

89. Oen, I.; van Baar, M.E.; Middelkoop, E.; Nieuwenhuis, M.K. Effectiveness of cerium nitrate-silver sulfadiazine in the treatment of facial burns: A multicenter, randomized, controlled trial. Plast. Reconstr. Surg. 2012, 130, 274e-283e. [CrossRef] [PubMed]

90. Heyneman, A.; Hoeksema, H.; Vandekerckhove, D.; Pirayesh, A.; Monstrey, S. The role of silver sulphadiazine in the conservative treatment of partial thickness burn wounds: A systematic review. Burns 2016, 42, 1377-1386. [CrossRef] [PubMed]

91. Wasiak, J.; Cleland, H.; Campbell, F.; Spinks, A. Dressings for superficial and partial thickness burns. Cochrane Database Syst. Rev. 2013, 2013, CD002106. [CrossRef] [PubMed]

92. Khundkar, R.; Malic, C.; Burge, T. Use of Acticoat dressings in burns: What is the evidence? Burns 2010, 36, 751-758. [CrossRef]

93. Gravante, G.; Caruso, R.; Sorge, R.; Nicoli, F.; Gentile, P.; Cervelli, V. Nanocrystalline silver: A systematic review of randomized trials conducted on burned patients and an evidence-based assessment of potential advantages over older silver formulations Ann. Plast. Surg. 2009, 63, 201-205. [CrossRef]

94. Yarboro, D.D. A comparative study of the dressings silver sulfadiazine and Aquacel Ag in the management of superficial partial-thickness burns. Adv. Skin. Wound Care 2013, 26, 259-262. [CrossRef]

95. Muangman, P.; Pundee, C.; Opasanon, S.; Muangman, S. A prospective, randomized trial of silver containing hydrofiber dressing versus $1 \%$ silver sulfadiazine for the treatment of partial thickness burns. Int. Wound J. 2010, 7, 271-276. [CrossRef]

96. Huang, Y.; Li, X.; Liao, Z.; Zhang, G.; Liu, Q.; Tang, J.; Peng, Y.; Liu, X.; Luo, Q. A randomized comparative trial between Acticoat and SD-Ag in the treatment of residual burn wounds, including safety analysis. Burns 2007, 33, 161-166. [CrossRef] [PubMed]

97. Abraham, G.E. The history of iodine in medicine part I: From discovery to essentiality. Orig. Internist 2006, 13, $29-36$.

98. Han, K.H.; Maitra, A.K. Management of partial skin thickness burn wounds with Inadine dressings. Burns 1989, 15, 399-402. [CrossRef]

99. Homann, H.H.; Rosbach, O.; Moll, W.; Vogt, P.M.; Germann, G.; Hopp, M.; Langer-Brauburger, B.; Reimer, K.; Steinau, H.U. A liposome hydrogel with polyvinyl-pyrrolidone iodine in the local treatment of partial-thickness burn wounds. Ann. Plast. Surg. 2007, 59, 423-427. [CrossRef]

100. Sinha, R.; Agarwal, R.K.; Agarwal, M. Povidone iodine plus neosporin in superficial burns—A continuing study. Burns 1997, 23, 626-628. [CrossRef]

101. Slaviero, L.; Avruscio, G.; Vindigni, V.; Tocco-Tussardi, I. Antiseptics for burns: A review of the evidence. Ann. Burn. Fire Disasters 2018, 31, 198-203.

102. Molan, P.C. The role of honey in the management of wounds. J. Wound Care 1999, 8, 415-418. [CrossRef]

103. Al-Waili, N.S.; Salom, K.; Butler, G.; Al Ghamdi, A.A. Honey and microbial infections: A review supporting the use of honey for microbial control. J. Med. Food 2011, 14, 1079-1096. [CrossRef]

104. Gupta, S.S.; Singh, O.; Bhagel, P.S.; Moses, S.; Shukla, S.; Mathur, R.K. Honey dressing versus silver sulfadiazene dressing for wound healing in burn patients: A retrospective study. J. Cutan. Aesthet. Surg. 2011, 4, 183-187. [CrossRef]

105. Lindberg, T.; Andersson, O.; Palm, M.; Fagerstrom, C. A systematic review and meta-analysis of dressings used for wound healing: The efficiency of honey compared to silver on burns. Contemp. Nurse 2015, 51, 121-134. [CrossRef]

106. Aziz, Z.; Hassan, B.A.R. The effects of honey compared to silver sulfadiazine for the treatment of burns: A systematic review of randomized controlled trials. Burns 2017, 43, 50-57. [CrossRef] [PubMed]

107. Malik, K.I.; Malik, M.A.; Aslam, A. Honey compared with silver sulphadiazine in the treatment of superficial partial-thickness burns. Int. Wound J. 2010, 7, 413-417. [CrossRef] [PubMed]

108. Afshari, A.; Nguyen, L.; Kahn, S.A.; Summitt, B. 2.5\% Mafenide Acetate: A Cost-Effective Alternative to the 5\% Solution for Burn Wounds. I. Burn Care Res. 2017, 38, e42-e47. [CrossRef]

109. Kucan, J.O.; Smoot, E.C. Five percent mafenide acetate solution in the treatment of thermal injuries. J. Burn. Care Rehabil. 1993, 14, 158-163. [CrossRef] [PubMed]

110. Maggi, S.P.; Soler, P.M.; Smith, P.D.; Hill, D.P.; Ko, F.; Robson, M.C. The efficacy of 5\% Sulfamylon solution for the treatment of contaminated explanted human meshed skin grafts. Burns 1999, 25, 237-241. [CrossRef]

111. Gray, J.H.; Henry, D.A.; Forbes, M.; Germann, E.; Roberts, F.J.; Snelling, C.F. Comparison of silver sulphadiazine 1 per cent, silver sulphadiazine 1 per cent plus chlorhexidine digluconate 0.2 per cent and mafenide acetate 8.5 per cent for topical antibacterial effect in infected full skin thickness rat burn wounds. Burns 1991, 17, 37-40. [CrossRef]

112. Shuck, J.M.; Moncrief, J.A. The management of burns. I. General considerations and the sulfamylon method. Curr. Probl. Surg. $1969,6,3-52$

113. Neely, A.N.; Gardner, J.; Durkee, P.; Warden, G.D.; Greenhalgh, D.G.; Gallagher, J.J.; Herndon, D.N.; Tompkins, R.G.; Kagan, R.J. Are topical antimicrobials effective against bacteria that are highly resistant to systemic antibiotics? J. Burn Care Res. 2009, 30, 19-29. [CrossRef]

114. Moncrief, J.A.; Lindberg, R.B.; Switzer, W.E.; Pruitt, B.A., Jr. Use of topical antibacterial therapy in the treatment of the burn wound. Arch. Surg. 1966, 92, 558-565. [CrossRef]

115. Shuck, J.M.; Moncrief, J.A. Safeguards in the use of topical mafenide (Sulfamylon) in burned patients. Am. J. Surg. 1969, 118, 864-870. [CrossRef]

116. Curreri, P.W.; Shuck, J.M.; Flemma, R.J.; Lindberg, R.D.; Pruitt, B.A., Jr. Treatment of burn wounds with five per cent aqueous sulfamylon and occlusive dressings. Surg. Forum. 1969, 20, 506-507. [CrossRef] [PubMed] 
117. Harrison, H.N.; Bales, H.W.; Jacoby, F. The absorption into burned skin of Sulfamylon acetate from 5 per cent aqueous solution. J. Trauma 1972, 12, 994-998. [CrossRef]

118. Harrison, H.N.; Shuck, J.M.; Caldwell, E. Studies of the pain produced by mafenide acetate preparations in burns. Arch. Surg. 1975, 110, 1446. [CrossRef] [PubMed]

119. Lee, K.C.; Joory, K.; Moiemen, N.S. History of burns: The past, present and the future. Burn. Trauma 2014, 2, 169-180. [CrossRef]

120. Young, F. Immediate Skin Grafting in the Treatment of Burns: A Preliminary Report. Ann. Surg. 1942, 116, 445-451. [CrossRef] [PubMed]

121. Saltonstall, H.; Lee, W.E. Modified Technic in Skin Grafting of Extensive Deep Burns. Ann. Surg. 1944, 119, 690-693. [CrossRef]

122. Jackson, D.; Topley, E.; Cason, J.S.; Lowbury, E.J. Primary excision and grafting of large burns. Ann. Surg. 1960, 152, 167-189. [CrossRef]

123. Janzekovic, Z. A new concept in the early excision and immediate grafting of burns. J. Trauma 1970, 10, 1103-1108. [CrossRef]

124. Monafo, W.W. Tangential excision. Clin. Plast. Surg. 1974, 1, 591-601. [CrossRef]

125. Engrav, L.H.; Heimbach, D.M.; Reus, J.L.; Harnar, T.J.; Marvin, J.A. Early excision and grafting vs. nonoperative treatment of burns of indeterminant depth: A randomized prospective study. J. Trauma 1983, 23, 1001-1004. [CrossRef]

126. Tompkins, R.G.; Burke, J.F.; Schoenfeld, D.A.; Bondoc, C.C.; Quinby, W.C., Jr.; Behringer, G.C.; Ackroyd, F.W. Prompt eschar excision: A treatment system contributing to reduced burn mortality. A statistical evaluation of burn care at the Massachusetts General Hospital (1974-1984). Ann. Surg. 1986, 204, 272-281. [CrossRef] [PubMed]

127. Saaiq, M.; Zaib, S.; Ahmad, S. Early excision and grafting versus delayed excision and grafting of deep thermal burns up to $40 \%$ total body surface area: A comparison of outcome. Ann. Burn. Fire Disasters 2012, 25, 143-147.

128. Pietsch, J.B.; Netscher, D.T.; Nagaraj, H.S.; Groff, D.B. Early excision of major burns in children: Effect on morbidity and mortality. J. Pediatr. Surg. 1985, 20, 754-757. [CrossRef]

129. Irei, M.; Abston, S.; Bonds, E.; Rutan, T.; Desai, M.; Herndon, D.N. The optimal time for excision of scald burns in toddlers. J. Burn. Care Rehabil. 1986, 7, 508-510. [CrossRef] [PubMed]

130. Ong, Y.S.; Samuel, M.; Song, C. Meta-analysis of early excision of burns. Burns 2006, 32, 145-150. [CrossRef]

131. Demling, R.H. Improved survival after massive burns. J. Trauma 1983, 23, 179-184. [CrossRef]

132. Moussa, A.; Lo, C.H.; Cleland, H. Burn wound excision within 24 h: A 9-year review. Burns 2021, 47, 1300-1307. [CrossRef]

133. Huang, C.; Leavitt, T.; Bayer, L.R.; Orgill, D.P. Effect of negative pressure wound therapy on wound healing. Curr. Probl. Surg. 2014, 51, 301-331. [CrossRef]

134. Dumville, J.C.; Munson, C.; Christie, J. Negative pressure wound therapy for partial-thickness burns. Cochrane Database Syst. Rev. 2014, 12, CD006215. [CrossRef]

135. Lin, D.Z.; Kao, Y.C.; Chen, C.; Wang, H.J.; Chiu, W.K. Negative pressure wound therapy for burn patients: A meta-analysis and systematic review. Int. Wound J. 2021, 18, 112-123. [CrossRef]

136. Nuutila, K.; Yang, L.; Broomhead, M.; Proppe, K.; Eriksson, E. Novel negative pressure wound therapy device without foam or gauze is effective at $-50 \mathrm{mmHg}$. Wound Repair. Regen. 2019, 27, 162-169. [CrossRef] [PubMed]

137. Shine, J.; Efanov, J.I.; Paek, L.; Coeugniet, E.; Danino, M.A.; Izadpanah, A. Negative pressure wound therapy as a definitive treatment for upper extremity wound defects: A systematic review. Int. Wound J. 2019, 16, 960-967. [CrossRef]

138. Kantak, N.A.; Mistry, R.; Varon, D.E.; Halvorson, E.G. Negative Pressure Wound Therapy for Burns. Clin. Plast. Surg. 2017, 44, 671-677. [CrossRef] [PubMed]

139. Wiechula, R. The use of moist wound-healing dressings in the management of split-thickness skin graft donor sites: A systematic review. Int. J. Nurs Pract. 2003, 9, S9-S17. [CrossRef] [PubMed]

140. Kamolz, L.P.; Andel, H.; Haslik, W.; Winter, W.; Meissl, G.; Frey, M. Use of subatmospheric pressure therapy to prevent burn wound progression in human: First experiences. Burns 2004, 30, 253-258. [CrossRef]

141. Llanos, S.; Danilla, S.; Barraza, C.; Armijo, E.; Pineros, J.L.; Quintas, M.; Searle, S.; Calderon, W. Effectiveness of negative pressure closure in the integration of split thickness skin grafts: A randomized, double-masked, controlled trial. Ann. Surg. 2006, 244, 700-705. [CrossRef]

142. Petkar, K.S.; Dhanraj, P.; Kingsly, P.M.; Sreekar, H.; Lakshmanarao, A.; Lamba, S.; Shetty, R.; Zachariah, J.R. A prospective randomized controlled trial comparing negative pressure dressing and conventional dressing methods on split-thickness skin grafts in burned patients. Burns 2011, 37, 925-929. [CrossRef]

143. Genecov, D.G.; Schneider, A.M.; Morykwas, M.J.; Parker, D.; White, W.L.; Argenta, L.C. A controlled subatmospheric pressure dressing increases the rate of skin graft donor site reepithelialization. Ann. Plast. Surg. 1998, 40, 219-225. [CrossRef]

144. Chong, S.J.; Liang, W.H.; Tan, B.K. Use of multiple VAC devices in the management of extensive burns: The total body wrap concept. Burns 2010, 36, e127-e129. [CrossRef]

145. Stone Ii, R.; Natesan, S.; Kowalczewski, C.J.; Mangum, L.H.; Clay, N.E.; Clohessy, R.M.; Carlsson, A.H.; Tassin, D.H.; Chan, R.K.; Rizzo, J.A.; et al. Advancements in Regenerative Strategies Through the Continuum of Burn Care. Front. Pharmacol. 2018, 9, 672. [CrossRef]

146. Girdner, J. Skin grafting with grafts taken from the dead subject. Med. Rec. 1881, 20, 119-120.

147. Jackson, D. A clinical study of the use of skin homografts for burns. Br. J. Plast. Surg. 1954, 7, 26-43. [CrossRef]

148. Alexander, J.W.; MacMillan, B.G.; Law, E.; Kittur, D.S. Treatment of severe burns with widely meshed skin autograft and meshed skin allograft overlay. J. Trauma 1981, 21, 433-438. [PubMed] 
149. Boateng, J.S.; Matthews, K.H.; Stevens, H.N.; Eccleston, G.M. Wound healing dressings and drug delivery systems: A review. J. Pharm. Sci. 2008, 97, 2892-2923. [CrossRef]

150. Oryan, A.; Alemzadeh, E.; Moshiri, A. Burn wound healing: Present concepts, treatment strategies and future directions. J. Wound Care 2017, 26, 5-19. [CrossRef]

151. Chen, L.; Xing, Q.; Zhai, Q.; Tahtinen, M.; Zhou, F.; Chen, L.; Xu, Y.; Qi, S.; Zhao, F. Pre-vascularization Enhances Therapeutic Effects of Human Mesenchymal Stem Cell Sheets in Full Thickness Skin Wound Repair. Theranostics 2017, 7, 117-131. [CrossRef]

152. Morimoto, N.; Saso, Y.; Tomihata, K.; Taira, T.; Takahashi, Y.; Ohta, M.; Suzuki, S. Viability and function of autologous and allogeneic fibroblasts seeded in dermal substitutes after implantation. J. Surg. Res. 2005, 125, 56-67. [CrossRef]

153. Tonello, C.; Vindigni, V.; Zavan, B.; Abatangelo, S.; Abatangelo, G.; Brun, P.; Cortivo, R. In vitro reconstruction of an endothelialized skin substitute provided with a microcapillary network using biopolymer scaffolds. FASEB J. 2005, 19, 1546-1548. [CrossRef]

154. Biedermann, T.; Klar, A.S.; Bottcher-Haberzeth, S.; Michalczyk, T.; Schiestl, C.; Reichmann, E.; Meuli, M. Long-term expression pattern of melanocyte markers in light- and dark-pigmented dermo-epidermal cultured human skin substitutes. Pediatr. Surg. Int. 2015, 31, 69-76. [CrossRef]

155. Abazari, M.; Ghaffari, A.; Rashidzadeh, H.; Momeni Badeleh, S.; Maleki, Y. Current status and future outlook of nano-based systems for burn wound management. J. Biomed. Mater. Res. B Appl. Biomater. 2020, 108, 1934-1952. [CrossRef] 